\title{
MENILIK PENGHINDARAN PAJAK DI PERUSAHAAN PERTAMBANGAN
}

\author{
Dhinda Nuramalia ${ }^{1}$, Dianwicaksih Arieftiara ${ }^{2}$, Noegrahini Lastiningsih ${ }^{3}$ \\ 1,2,3Universitas Pembangunan Nasional Veteran Jakarta, Jakarta, Indonesia \\ Email korespondensi: ${ }^{1}$ dhinda.nuramalia@upnvj.ac.id
}

\begin{abstract}
ABSTRAK
Penelitian ini merupakan penelitian kuantitatif yang bertujuan untuk menganalisis pengaruh pengungkapan corporate social responsibility, kepemilikan institusional, dan profitabilitas terhadap agresivitas pajak. Populasi pada penelitian ini adalah seluruh perseroan pertambangan yang terdaftar di Bursa Efek Indonesia tahun 2016-2020 dan sampel penelitian dipilih menggunakan teknik purposive sampling. Analisis data penelitian menggunakan metode regresi linear berganda. Penelitian ini memberikan implikasi bahwa pada perusahaan pertambangan khususnya pada kurun waktu penelitan, aktivitas manajer terkait tanggung jawabnya terhadap lingkungan dan masyarakat tidak berorientasi pada pajak perusahaan, tetapi benar bermotifkan perhatian akan keberlanjutan operasional perusahaan (sustainability operation). Demikian pula pemilik yang berasal dari institusi melakukan pengawasan dan pengendalian manajer pada aspek strategis selain pajak perusahaan. Dari hasil riset ini terbukti pula bahwa profitabilitas perusahaan tidak menjadi hal yang dapat mendorong manajer melakukan aktivitas penghindaran pajak, terlebih pada saat masa pandemi sekarang ini banyak sekali insentif dan kebijakan yang dikeluarkan oleh Dirjen pajak untuk mendorong keberlangsungan ekonomi wajib pajak.
\end{abstract}

Kata Kunci: agresivitas pajak; composite measurement; kepemilikan institusional; pengungkapan corporate social responsibilty; profitabilitas.

\begin{abstract}
This study is a quantitative study that aims to analyze the effect of the use of corporate social responsibility, institutional ownership, and profitability on tax aggressiveness. The population of this study were all mining companies listed on the Indonesia Stock Exchange in 2016-2020 and the research sample was selected using a purposive sampling technique. Analysis of research data using multiple linear regression method. This study shows that in mining companies, especially at the time of the study, activities related to environmental and community management are not related to corporate taxes, but are very beneficial for company operations. Likewise, owners who come from institutions that supervise and control managers in other strategic aspects besides corporate taxes. From the results of this study, it is also proven that company profitability is not something that can encourage managers to carry out tax avoidance activities, especially during the current pandemic, there are lots of incentives and policies issued by the Director General of Taxes to encourage the economic sustainability of taxpayers.
\end{abstract}

Keywords: composite measuremnet tax avoidance; corporate social responsibilty disclosure; institutional ownership; profitability; tax aggressiveness.

\section{KETERANGAN ARTIKEL}

Riwayat Artikel: diterima: 4 Agustus 2021; direvisi: 3 Desember 2021; disetujui: 10 Desember 2021

Klasifikasi JEL: H25

Cara mensitasi: Nuramalia, D., Arieftiara, D., \& Lastiningsih, N. (2021). Menilik Penghindaran Pajak di Perusahaan Pertambangan. JIAFE (Jurnal Ilmiah Akuntansi Fakultas Ekonomi), 7(2), $201-214$. https://doi.org/10.34204/jiafe.v7i2.3697 
Dhinda Nuramalia: Menilik Penghindaraan Pajak ...

\section{PENDAHULUAN}

Pandangan mengenai pajak dari sisi pemerintah dan perseroan memiliki perbedaan, yaitu pemerintah yang berupaya keras untuk merealisasikan target pajak yang telah ditetapkan guna membiayai belanja negara seperti pembangunan infrastruktur negara yang dapat dinikmati oleh semua masyarakat, sementara dari sisi perseroan menginginkan tujuannya tercapai yakni memaksimalkan laba dan berorientasi pada shareholder (Jurnal Enterpreneurship, 2021). Berbagai kendala dihadapi oleh negara dalam memungut pajak dari wajib pajak salah satunya adanya tindakan agresivitas pajak. Tindakan ini dapat mengurangi penerimaan pajak yang diterima oleh pemerintah karena tidak terealisasi penerimaan negara yang sudah ditargetkan karena banyak perseroan yang berusaha untuk melakukan perbuatan penghindaran pajak dengan tujuan pajak yang dibayarkan menjadi berkurang (Zsazya, 2019). Frank, dkk. (2009) mengartikan bahwa kegiatan agresivitas pajak yakni salah satu usaha perseroan meminimalkan pajak yang dibayar dengan sebuah cara yakni melakukan rekayasasa penghasilan kena pajak, yang sebelumnya telah dilakukan perencanaan pajak, perencanaan pajak ini terbagi dua yakni tindakan yang legal (tax avoidance) dan illegal (tax evasion).

Selain kendala tersebut, ada kendala eksternal yang tidak terduga oleh seluruh dunia yakni adanya virus corona yang dinyatakan sebagai pandemi pada akhir tahun 2019 lalu. Pandemi covid-19 yang terjadi di hampir seluruh dunia, dan memberikan dampak yang sangat besar seperti banyak negaranegara yang mengalami resesi akibat terjadinya pandemi ini, virus covid-19 melemahkan berbagai aspek pertumbuhan ekonomi diseluruh negara. Perseroan banyak yang mengalami kebangkrutan akibat tidak dapat bersaing dan tidak mampu membiayai kegiatan operasional perseroan, dampaknya terjadi pemutusan kerja oleh perseroan, lonjakan pengangguran semakin tinggi, dan daya konsumsi masyarakat mengalami penurunan. Dengan adanya situasi pandemi covid-19 ini banyak sektor penerimaan pajak yang mengalami penurunan, hal ini berdampak pada perlambatan ekonomi (Warsito \& Lindiasari, 2020). Dalam PMK Nomor 9/PMK.03/2021 pemerintah mengambil kebijakan untuk melakukan insentif pajak dan relaksasi yakni insentif PPh pasal 21, 22, 25, PPN, Pajak UMKM, selain itu relaksasi yang pemerintah berikan yakni penurunan tarif PPh badan, perpanjangan waktu permohonan dan perpanjangan masa lapor SPT. Hal tersebut dilakukan agar penerimaan dari pajak tetap dapat diterima oleh pemerintah.

Saat ini pemerintah memerlukan banyak penerimaan pajak untuk pembangunan dibidang kesehatan agar masyarakat dapat menggunakan fasilitas tersebut dalam menghadapi pandemi covid-19 dengan mengingat virus ini sangat mudah tertular yang semakin hari semakin banyak masyarakat yang terpapar virus ini. Pandemi covid-19 ini melemahkan keuangan global, dibuktikan dengan adanya perubahan target APBN 2020 yang semula Rp1.699,94 triliun menjadi Rp1.198,8 triliun diubah melalui Perpres 72/2020. Penurunan yang cukup signifikan pada tahun 2020 karena pemerintah banyak memberikan insentif pajak dan seluruh sektor perekonomian melemah. Perseroan yang tidak dapat bersaing harus mengalami gulung tikar agar dapat menutupi biaya operasional akibat rendahnya pendapatan yang diterima, di saat yang sama perseroan memiliki kewajiban membayar pajak dan melakukan tanggung jawab sosialnya pada masyarakat pada saat sisi kesehatan keuangan perseroan mengalami ketidakstabilan atau cenderung merugi. Dalam hal ini maka dengan terjadinya pandemi covid-19 membuat banyak perseroan berusaha untuk menghindari pajak dengan melakukan agresivitas karena penerimaan mereka menurun sangat drastis. 
Tabel 1. Realisasi Penerimaan dan Target Pajak Tahun 2016-2020

\begin{tabular}{cccc}
\hline Tahun & $\begin{array}{c}\text { Target Penerimaan Pajak } \\
\text { (dalam triliun) }\end{array}$ & $\begin{array}{c}\text { Realisasi Penerimaan } \\
\text { pajak (dalam triliun) }\end{array}$ & $\begin{array}{c}\text { Persentase } \\
\text { (\%) }\end{array}$ \\
\hline 2016 & Rp1.355,20 & Rp1.105,97 & 81,61 \\
2017 & $\mathrm{Rp} 1.472,20$ & $\mathrm{Rp} 1.339,80$ & 90,98 \\
2018 & $\mathrm{Rp} 1.618,10$ & $\mathrm{Rp} 1.521 .40$ & 94,02 \\
2019 & $\mathrm{Rp} 1.577,60$ & $\mathrm{Rp} 1.332,10$ & 84,44 \\
2020 & $\mathrm{Rp} 1.198,80$ & $\mathrm{Rp} 1.019,56$ & 85,65 \\
\hline
\end{tabular}

Sumber: Setiawan (2020)

Merujuk Tabel 1 diketahui persentase realisasi pendapatan pajak dan target pendapatan pajak tidak konsisten meningkat. Pada tahun 2016 persentase target pendapatan pajak dibagi dengan realisasi penerimaan pajak sebesar 81,61\%, pada 2017 persentase meningkat menjadi 90,98\% dan tahun 2018 kembali meningkat mencapai 94,02\% penerimaan dari target yang ditentukan, pada tahun 2019 hal tersebut berbanding terbalik dan cenderung menurun hampir $10 \%$ yakni pada angka $84,44 \%$, pada tahun 2020 di akibatkan adanya pandemi covid-19 yang menyebabkan perekonomian lumpuh tetapi berhasil meningkat dari tahun 2019 yakni 85,65\%. Naik turunnya persentase pendapatan pajak dapat dipengaruhi oleh berbagai macam faktor di antaranya terdapat faktor ekonomi, faktor perpajakan yang meliputi kepatuhan pajak, aktivitas wajib pajak dalam penghindaran pajak. Selain itu dapat disebabkan oleh rendahnya tingkat tax ratio di Indonesia, tax ratio yang rendah dapat dipengaruhi oleh bermacammacam faktor salah satunya yakni masih terdapat celah untuk melakukan penghindaran pajak karena kebijakan perpajakan masih lemah oleh pengawasan yang dapat mendorong para wajib pajak untuk melakukan penghindaran. Tahun 2018 PDB (Produk Domestik Bruto) Indonesia sebesar 11,5\%, persentase ini merupakan persentase yang tergolong rendah jika dibandingkan dengan negara berkembang lainnya yang persentase PDB-nya dapat mencapai angka $27,8 \%$. Sementara itu pada tahun 2019 tax ratio Indonesia kembali turun persentase-nya hanya sebesar 10,73\% dan tahun 2020 tax ratio Indonesia hanya sebesar 7,90\% dari PDB.

Dian Patria selaku Direktorat Litbang KPK memberikan data bahwa untuk tahun 2016 perseroan yang memiliki aktivitas operasi di bidang pertambangan rata-rata melakukan penghindaran pajak. Dari data yang ada sebanyak 11.000 izin pertambangan, ada 4.000 perseroan yang nonclear and clear yang izinnya tumpang tindih sehingga sebagian besar tidak membayarkan pajaknya (Redaksi Klinik Pajak, 2016).

Menurut Wiko Saputra, Peneliti Kebijakan Ekonomi Transaksi Terbayar (PWYP) di Indonesia, mengatakan bahwa aliran dana ilegal di industri pertambangan disebabkan oleh pemalsuan transaksi faktur atau kesalahan faktur yang disebabkan oleh maraknya aktivitas penambangan liar dan ekspor komoditas tambang yang tidak tercatat. KPK (Komisi Pemberantasan Korupsi) mendapati total perseroan pertambangan yang tidak mematuhi aturan perpajakan di Indonesia (Nuraeni, 2015). Misalnya, merujuk hasil koordinasi dan pengawasan KPK yang dilakukan oleh Administrasi Perpajakan Negara dengan Kementerian ESDM serta lembaga terkait yang menjelaskan bahwa dari sebanyak 7.834 perseroan yang tercatat di Administrasi Perpajakan Negara, 24\% perseroan diketahui tidak memiliki Nomor Pokok Wajib Pajak (NPWP), dan sebesar 35\% perseroan tidak melaporkan Surat Pemberitahuan (SPT).

Terdapat sudut pandang lain mengenai permasalahan rendahnya penerimaan pajak dari sektor batu bara yakni masih lemah atau belum maksimal wewenang dari otoritas pajak dan fiskus dalam pemeriksaan bagi para wajib pajak mengenai kebenaran pembayaran pajaknya sehingga pada saat 
Dhinda Nuramalia: Menilik Penghindaraan Pajak ...

otoritas pajak mengajukan sengketa pajak di pengadilan selalu kalah oleh wajib pajak. Salah satu contoh dugaan penghindaran pajak yakni kasus perseroan batu bara PT Multi Sarana Avindo (MSA), kasus ini terjadi karena dugaan MSA kurang bayar pajak pertambahan nilai (PPN). Direktorat Jenderal Pajak yang memiliki otoritas melayangkan dakwaan pada tahun 2007, 2009, dan 2010. DJP mendakwa MSA dengan nomimal senilai 7,7 miliar tetapi gugatan DJP tersebut kalah di pengadilan pajak karena secara materiil tidak terbukti. Tahun 2018 DJP kembali melayangkan dakwaan yang sama terhadap MSA, DJP mencurigainya karena adanya sejumlah modifikasi yang signifikan antara besaran produksi dengan total pembayaran pajaknya. Akhirnya, DJP dapat mengungkapkan angka-angka yang disajikan oleh MSA pada laporan keuangannya.

Salah satu contoh di atas menjadi bukti bahwa adanya praktik agresivitas pajak yang dilakukan oleh perseroan, selain kasus agresivitas pajak terdapat kasus praktik CSR yang tengah menjadi perhatian serius bagi pemerintah dan warga sekitar tempat perseroan beroperasi karena telah terjadi kerusakan alam, contoh kasusnya terjadi pada tahun 2009 PT Adaro Energy Tbk melakukan pencemaran air, limbah pengendapan yang dihasilkan Adaro mencemari sungai yang berakibat pencemaran air disekitar lingkungan perseroan beroperasi yakni sungai balangan dan empat kecamatan lainnya. Akibat pencemaran air, air sungai menjadi berwarna coklat yang berakibat tidak dapat digunakan oleh warga dan penyebaran air dari PDAM Amuntai juga ikut terhenti karena sumber air yang dihasilkan di Desa Tangga ulin juga ikut tercemar. Pencemaran air yang terjadi di sungai balangan merugikan secara materi yang nilainya diperkirakan hingga miliaran rupiah hal ini karena terdapat usaha budidaya ikan banyak yang mati akibat air yang tercemar (Rahman, 2009).

Menurut Lanis \& Richardson (2013) dari sudut pandang masyarakat bahwa perseroan yang melakukan upaya pajak agresif yakni perbuatan yang tidak bertanggung jawab atas sosial dan tidak benar. CSR dapat dikatakan sebagai keberhasilan dan kelangsungan hidup perseroan, aktivitas yang dilakukan perseroan berdampingan erat dengan masyarakat sekitar. Perseroan berusaha untuk meraih citra yang positif di masyarakat dengan menunjukkan-nya kepada publik dengan cara mengungkapkan aktivitas CSR yang perseroan lakukan untuk masyarakat. Perseroan mengungkapkan CSR di dalam laporan tahunan dan terdapat juga sustainability report yang menjadi kelemahan dalam pengungkapan CSR yakni tidak ada standar baku bentuk pelaporan yang seharusnya dibuat dan dipublikasi oleh perseroan.

Hubungan antara kepemilikan institusional dengan agresivitas pajak yakni institusi memiliki sikap profesional dalam memantau, mengawasi dan melakukan pengendalian terhadap manajemen atas investasi yang ditanamkan, maka semakin besar suatu institusi memiliki saham dalam perseroan diikuti dengan pengawasan dan pengendalian yang dilakukan agar dapat memantau aktivitas manajemen untuk melakukan tindakan manajemen pajak kecil dan kemungkinan untuk manajemen melakukan penghindaran pajak juga semakin kecil (Hakim, 2020).

Hubungan antara profitabilitas terhadap agresivitas pajak, yakni menurut Reminda (2017) bahwa organisasi yang memiliki laba tinggi akan menjadi sorotan masyarakat dan bagi pemerintah karena pembayaran pajak yang tinggi searah dengan pendapatan yang diterima. Tujuan utama perseroan yakni memaksimalkan laba, perihal ini dapat memotivasi perseroan dalam menggunakan berbagai cara untuk meminimalkan beban pajaknya seperti menggunakan metode akuntansi yang dapat mengurangi profit sehingga pengeluaran pajak yang ditimbulkan menjadi minim.

Penelitian kali ini, peneliti menggunakan tiga variabel kontrol guna meminimalisir adanya pengaruh lain selain variabel independen yang digunakan, kontrol variabel yang peneliti gunakan dalam riset yakni leverage, ukuran perusahaan dan umur perusahaan. Menurut peneliti tiga variabel ini dapat mengendalikan, seperti leverage dapat dinyatakan kemampuan yang di lakukan oleh perseroan guna memenuhi finansial atau keuangan jangka pendek dan jangka panjang, ukuran perusahaan dapat 
dinyatakan jika semakin besar ukuran perusahaan akan timbul pengawasan yang lebih besar dari pemerintah dan umur perusahaan dinyatakan lamanya perseroan beroperasi dapat mengontrol perbedaan pengalaman yang perseroan lakukan dalam menghindari pajak.

Merujuk hasil riset terdahulu yang dilakukan Wijaya \& Saebani (2019) menjelaskan hasil pengungkapan corporate social responsibility (CSR) berpengaruh signifikan negatif terhadap CETR. Hal serupa ditemukan oleh Suprimarini \& Suprasto (2017), Adiputra dkk. (2019) pada penelitiannya bahwa secara signifikan negatif agresivitas pajak dipengaruhi oleh Corporate social responsibility. Hasil berbeda ditunjukkan oleh penelitian yang dilakukan oleh Jessica (2014) menjelaskan bahwa secara signfikan agresivitas pajak tidak dipengaruhi oleh corporate social responsibility. Pada variabel kepemilikan institusional hasil penelitian yang dilakukan oleh Sujudi dkk. (2019) menjelaskan hasil kepemilikan institusional berpengaruh terhadap tax avoidance. Hal serupa ditemukan pada penelitian yang dilakukan oleh Pranata dkk. (2014). Namun, hasil berbeda ditunjukkan oleh penelitian yang dilakukan oleh Suprimarini \& Suprasto (2017) bahwa agresivitas pajak tidak dipengaruhi oleh kepemilikan institusional, sedangkan untuk variabel profitabilitas hasil penelitian yang dilakukan oleh Reminda (2017) menjelaskan hasil Profitabilitas berpengaruh signifikan terhadap Agresivitas Pajak. Hal berbeda ditemukan dalam penelitian Rista \& Mulyani (2019) bahwa penghindaran pajak secara signifikan tidak dipengaruhi oleh profitabilitas (ROA). Penelitian ini bertujuan untuk: pertama, menguji apakah ada pengaruh antara pengungkapan CSR (Corporate Social Responsibility) terhadap agresivitas pajak, kedua menganalisis apakah ada pengaruh antara kepemilikan institusional terhadap agresivitas pajak, dan ketiga, menguji apakah ada pengaruh antara profitabilitas terhadap agresivitas pajak.

\section{KAJIAN LITERATUR DAN PENGEMBANGAN HIPOTESIS TEORI AGENSI (AGENCY THEORY)}

Menurut Jensen and Meckling (1976) Agency theory timbul akibat terdapat perbedaan antara keinginan para pemegang saham (principal) dengan manajemen (agent), principal selaku investor tidak turun langsung dalam mengelola dan mengoperasikan jalan nya perseroan, pemegang saham hanya berkontribusi dalam menyiapkan dana untuk kegiatan operasional perseroan, sedangkan manajemen yang memiliki tanggung jawab untuk mengelola dana tersebut untuk kegiatan operasional perseroan. Perihal ini akan berdampak pada benturan kepentingan pemegang saham dan pihak manajemen.

\section{TEORI LEGITIMASI}

Teori legitimasi didasarkan oleh fenomena yang terjadi antara perseroan dengan penduduk sekitar, perseroan merupakan suatu organisasi memiliki tujuan atau harapan yang harus dibangun dengan nilainilai di masyarakat. Teori ini menjelaskan bahwa tindakan yang dilakukan oleh perseroan wajib mempunyai kegiatan dan program yang dapat diterima masyarakat. Teori legitimasi berarti perseroan wajib menerapkan kegiatan usahanya sesuai dengan batasan-batasan dalam norma-norma, nilai-nilai sosial di masyarakat dan responnya terhadap batasan guna menekan perilaku organisasi dengan mencermati area sekitar aktifitas usaha nya (Dowling \& Pfeffer, 1975).

Corporate social responsibility didefinisikan wujud usaha yang perseroan laksanakan dalam memperhitungkan sebab akibat sosial dan lingkungan yang ditimbulkan dari kegiatan operasional tetapi tetap dengan memaksimalkan manfaat dan menekankan total kerugian (Lanis \& Richardson, 2013). Berdasarkan pada teori legitimasi yang menyatakan bahwa CSR merupakan bentuk pertanggungjawaban perseroan terhadap masyarakat sekitar. Salah satu bentuk CSR yakni membayar pajak karena perseroan ikut berperan dalam andil pembangunan negara pernyataan ini mendukung bahwa pengungkapan corporate social responsibility berpengaruh signifikan pada tindakan agresivitas pajak. Selain membayar 
Dhinda Nuramalia: Menilik Penghindaraan Pajak ...

pajak, perseroan juga memiliki berbagai program CSR sebagai bentuk concern perseroan terhadap masyarakat. Pada penelitian sebelumnya oleh Adiputra dkk. (2019) memberikan pernyataan bahwa pengungkapan corporate social responsibility memiliki pengaruh signifikan negatif terhadap agresivitas pajak, maknanya pengungkapan tanggung jawab sosial dalam perihal ini berkenaan mengurangi tindakan pajak agresif karena dana perseroan digunakan untuk program yang berkaitan dengan tanggung jawab sosial tersebut. Sebagaimana. Penelitian yang dilakukan oleh Suprimarini \& Suprasto (2017) dan Prasista \& Setiawan (2016) mengartikan apabila terjadi peningkatan pengungkapan informasi CSR yang diungkap perseroan maka tingkat agresivitas pajaknya rendah. Tingkat agresivitas pajak yang rendah berarti nilai ETR-nya rendah karena pengungkapan CSR oleh perseroan semakin luas.

$H_{1}$ : pengungkapan CSR berpengaruh negatif terhadap agresivitas pajak.

Berdasarkan pada teori agensi, kaitannya dengan kepemilikan saham institusional yaitu pada pihak manajemen yang bertugas mengelola operasional perseroan berusaha untuk mengutamakan kepentingan principal. Hal ini dilakukan untuk meminimalisir konflik keagenan. Dengan adanya kepemilikan institusional menjelaskan bahwa agen memiliki tujuan yang sama dalam peningkatan laba perseroan dengan prinsipal sebagai pemegang saham. Teori ini menjelaskan antara kepemilikan institusional dengan agresivitas pajak karena semakin tinggi total persentase kepemilikan institusional maka pengawasan yang dilakukan akan semakin ketat. Merujuk hasil riset Hakim (2020) menunjukkan hasil penelitian kepemilikan saham institusional memiliki pengaruh negatif terhadap penghindaran pajak, persentase kepemilikan saham institusi tinggi menandakan bahwa rendahnya tindakan penghindaran pajak yang dilakukan perseroan. Pernyataan tersebut dapat terjadi karena institusi memiliki pengawasan yang lebih ketat dan memiliki kemampuan untuk menilai informasi. Hasil penelitian ini sejalan atau searah dengan penelitian Alkurdi \& Mardini (2020) dan Praditasari \& Setiawan (2017) yang mengartikan kepemilikan saham institusional akan berdampak pada pemantauan yang dilakukan perseroan dan dapat menekan manajer sehingga peluang terjadinya penghindaran pajak dapat diminimalisir.

\section{$\mathrm{H}_{2}$ : kepemilikan institusional berpengaruh positif terhadap agresivitas pajak.}

Berdasarkan teori agensi, antara profitabilitas dan agresivitas pajak, yakni ketika peningkatan profitabilitas perseroan maka agresivitas pajaknya juga semakin meningkat, mengingat bahwa pajak merupakan bagian dari kewajiban yang harus dikeluarkan oleh perseroan untuk pemerintah. Perseroan yang melakukan perbuatan pajak agresif yang akan memberikan dampak terhadap beban pajak yang dibayarkan menjadi minim, maka perolehan laba setelah dikurangi dengan biaya pajak akan tetap menghasilkan laba atau keuntungan yang tinggi. Merujuk hasil riset Prasista \& Setiawan (2016) dan Praditasari \& Setiawan (2017) bahwa nilai profitabilitas yang diukur dengan ROA jika nilai ROA tinggi maka searah dengan keuntungan yang diperoleh perseroan. Keuntungan yang dihasilkan perseroan menjadi dasar perhitungan dalam menetapkan besarnya total pajak yang dibayar maka dari itu perseroan akan berusaha atau berupaya menghindari peningkatan total pajak yang dibayarkan dengan usaha tax avoidance atau penghindaran pajak.

$H_{3}$ : profitabilitas berpengaruh positif terhadap agresivitas pajak.

\section{METODE PENELITIAN}

Jenis penelitian ini yakni deskriptif kuantitatif, jenis data yang digunakan yakni data sekunder yang berasal dari laporan tahunan, laporan keuangan, dan sustainability report perseroan pertambangan tahun 2016-2020 yang tersedia di situs Bursa Efek Indonesia atau website perseroan. Populasi yang peneliti gunakan di riset ini yakni perseroan pertambangan yang sahamnya listing di Bursa Efek Indonesia tahun 2016-2020. Teknik pengambilan sampling, dalam riset mengunakan purposive sampling yakni 
sampel yang dipilih hanya perseroan yang memenuhi persyaratan yang peneliti inginkan, antara lain perusahaan yang perseroan yang saham nya telah IPO (Initial Public Offering) pada tahun 2016 hingga 2020, mempublikasikan laporan tahunan, laporan keuangan dan ditambahkan dengan sustainability report pada tahun penelitian, memiliki kelengkapan data yang berhubungan dengan variabel yang diteliti yakni corporate social responsibility, kepemilikan institusional, dan profitabilitas. Jumlah sampel yang diperoleh peneliti atas kriteria yang telah ditetapkan sebanyak 110 data perusahaan dan dianalisis menggunakan regresi linear berganda.

Book Tax Difference (BTD), yakni perhitungan agresivitas pajak dengan menggunakan hasil perbedaan laba rugi sebelum pajak dengan perhitungan laba kena pajak. Merujuk pada Comprix dkk. (2011) pengukuran BTD dapat dirumuskan sebagai berikut:

$$
B T D_{i t}=B I_{i t}-\left(\frac{C T E_{i t}}{S T R_{i t}}\right)
$$

Abnormal BTD yakni perhitungan agresivitas pajak diukur dengan nilai residu total book tax difference. Merujuk Tang \& Firth (2011), rumus pengukuran Abn BTD yakni:

$$
\mathrm{BTD}_{\mathrm{it}}=\beta_{0}+\beta_{1} \Delta \mathrm{INV}_{\mathrm{it}}+\beta_{2} \mathrm{REV}_{\mathrm{it}}+\beta_{3} \mathrm{NOL}_{\mathrm{it}}+\beta_{4} \mathrm{TLU}_{\mathrm{it}}+\varepsilon_{\mathrm{it}}
$$

Abn Permanent Difference merupakan nilai residu dari komponen beda permanen, rumus Abn Permanent Difference Frank dkk. (2009) yakni:

$$
\text { PERMDIF }_{i t}=\alpha_{o}+\alpha_{1} \text { INTANG }_{i t}+\alpha_{2} \text { UNCON }_{i t}+\alpha_{3} \text { MI }_{i t}+\alpha_{4} \Delta \text { NOL }_{i t}+\alpha_{5} \text { LAGPERM }_{i t}+\varepsilon_{i t}
$$

Composite Measure of Tax Avoidance (CMTA) yakni nilai komposit yang digunakan pada 3 pengukuran agresivitas pajak yang terdiri dari Book tax difference, Abnormal Book Tax difference dan Abnormal permanent difference. Nilai agresivitas pajak pada masing-masing pengukuran yang peneliti gunakan dihitung dengan percentile rank, dan nilai CMTA yang dihasilkan masing-masing perseroan sebagai rata-rata dari total percentile rank. Apabila nilai CMTA tinggi maka dapat diartikan indikasi atau dugaaan perseroan melakukan agresivitas pajak juga tinggi, karena hal ini searah. Merujuk Arieftiara dkk. (2020) rumus CMTA yakni:

$\mathrm{CMTA}_{\mathrm{it}}=\left[\right.$ Percentil RankBTD $_{\mathrm{it}}+$ Percentil RankAbnBTD ${ }_{\mathrm{it}}+$ Percentil RankAbnPermdiff $\left._{\mathrm{it}}\right] \div 3$

Riset ini mengukur pengungkapan Corporate Social Responsibility dengan menggunakan indikator yang tertera pada GRI G4 dan GRI Standar yang dilihat dari laporan keberlanjutan (sustainability report) perseroan terkait yakni dengan cara melakukan pencocokan pada item-item yang diungkap pada daftar checklist. Penggabungan indikator pengukuran ini didasari atas penelitian Deswanto \& Siregar (2018) dan Ching dkk. (2017), penelitian ini menggabungkan indikator GRI G3 dan GRI G4.

$$
\operatorname{CSRDj}=\frac{\sum X i j}{n j}
$$

Kepemilikan institusional diharapkan dapat mendorong peningkatan pengawasan dan memonitor manajemen menjadi lebih optimal dan membuat perseroan memiliki tanggung jawab untuk para 
pemegang saham maka dari itu kepemilikan saham oleh institusi dapat menjadi pertimbangan untuk mendukung atau tidak mendukung keputusan yang diambil oleh manajemen. Rumus Kepemilikan Institusional Tandean \& Winnie (2016), yakni:

$$
K I=\frac{\text { Jumlah saham investor institusional }}{\text { Jumlah saham beredar }}
$$

Dalam mengukur tingkat profitabilitas perseroan, peneliti menggunakan ROA karena dapat membuktikan kemampuan perseroan dalam mendapatkan keuntungan yang diperoleh dari hasil pemanfaatan asset perseroan. Rumus ROA menurut Lanis and Grant Richardson (2013) yakni:

$$
R O A=\frac{\text { Pendapatan Sebelum Pajak }(\text { EBIT })}{\text { Total Aset }}
$$

Leverage dapat dinyatakan sebagai kemampuan yang di lakukan oleh perseroan guna memenuhi finansial atau keuangan jangka pendek dan jangka panjang. tingkat leverage menandakan perseroan sedang berusaha untuk meningkatkan labanya Andhari \& Sukartha (2017). Rumus pengukuran leverage yang digunakan yakni sebagai berikut:

$$
L E V=\frac{\text { Total Kewajiban Utang }}{\text { Total Ekuitas }}
$$

Makin besar ukuran perusahaan akan timbul pengawasan yang lebih besar dari pemerintah kepada perseroan karena perseroan yang besar memiliki tarif pajak efektif yang besar dan berusaha menghindari tindakan tax avoidance (Praditasari \& Setiawan, 2017). Rumus ukuran perusahaan yang digunakan yakni sebagai berikut:

$$
S I Z E=\ln (\text { total asset })
$$

Proksi kedewasaan perseroan dapat dilihat dari umur perusahaan karena lamanya perseroan beroperasi dapat mempengaruhi perbedaan pengalaman yang dilakukan perseroan dalam menghindari pajak (Arieftiara dkk., 2020). Rumus Umur perusahaan yang digunakan yakni:

$$
A G E=I P O-\text { Tahun Penelitian }
$$

Analisis data menggunakan analisis linear berganda dengan persamaan regresi berganda digambarkan sebagai berikut:

$$
\text { TAXAVOID }_{\text {it }}=\alpha-\beta_{1} \mathrm{CSR}_{\text {it }}-\beta_{2} \mathrm{KI}_{\text {it }}+\beta_{3} \mathrm{ROA}_{\text {it }}+\beta_{4} \mathrm{LEV}_{\text {it }}+\beta_{5} \mathrm{SIZE}_{i \mathrm{t}}+\beta_{6} \mathrm{AGE}_{\text {it }}+\varepsilon_{\text {it }}
$$

TAXAVOIDit adalah agresivitas pajak yang diukur dengan books tax different, abnormal books tax different, dan abnormal permanen different, $\alpha$ adalah konstanta, $\beta 1, \beta 2, \beta 3, \beta 4, \beta 5, \beta 6$ adalah koefisien regresi, $\mathrm{CSR}_{\text {it }}$ adalah corporate social responsibility, $\mathrm{KI}_{\text {it }}$ adalah kepemilikan Institusional, $\mathrm{ROA}_{i t}$ adalah profitabilitas, $\mathrm{LEV}_{\text {it }}$ adalah leverage, $\mathrm{SIZE}_{i t}$ adalah ukuran perusahaan, $\mathrm{AGE}_{\text {it }}$ adalah umur perusahaan, $\varepsilon_{\text {it }}$ adalah error term. 
JIAFE (Jurnal Ilmiah Akuntansi Fakultas Ekonomi)

Vol. 7 No. 2, Des 2021, Hal. 201-214

https://journal.unpak.ac.id/index.php/jiafe

P-ISSN: 2502-3020, E-ISSN: 2502-4159

\section{HASIL DAN PEMBAHASAN}

Tabel 2 menunjukkan gambaran atas data pada variabel penelitian, mencangkup mean, standar deviasi, nilai minimum, dan nilai maksimum.

Tabel 2. Statistik Deskriptif

\begin{tabular}{lcrrrr}
\hline \multicolumn{1}{c}{ Variabel } & Obs & \multicolumn{1}{c}{ Mean } & $\begin{array}{l}\text { Standar } \\
\text { Deviasi }\end{array}$ & Minimum & Maximum \\
\hline Composite & 110 & 0,498 & 0,204 & 0,012 & 0,963 \\
CSRIJ & 110 & 0,271 & 0,120 & 0,098 & 0,648 \\
KI & 110 & 0,160 & 0,270 & 0 & 0,814 \\
ROA_w & 110 & 0,111 & 0,129 & $-0,097$ & 0,472 \\
LEV_w & 110 & 0,878 & 0,984 & $-2,113$ & 3,383 \\
SIZE & 110 & 20,025 & 3,976 & 12,882 & 29,050 \\
Age & 110 & 13,590 & 7,576 & 1 & 30 \\
\hline
\end{tabular}

Berdasarkan Tabel 2 di atas, nilai mean agresivitas pajak yang diukur dengan Composite Measurement Tax Avoidance menunjukkan 0,498, menandakan bahwa perseroan yang termasuk ke dalam sampel tingkat penghindaran pajak nya moderat, karena rata-rata perseroan sampel diindikasikan melakukan penghindaran pajak sebesar $50 \%$ dari sampel. Nilai mean untuk variabel corporate social responsibility, yakni 0,271, menandakan bahwa perseroan sampel rata-rata mengungkapkan item corporate social responsibility sebesar $27 \%$. Nilai mean untuk variabel kepemilikan institusional, yakni 0,160 menandakan bahwa perseroan sampel rata-rata kepemilikan institusionalnya sebesar $16 \%$. Nilai mean variabel profitabilitas yakni 0,111 menandakan bahwa perseroan mampu menghasilakan keuntungan dari asetnya sebesar $11 \%$. Nilai mean variabel leverage sebesar 0,878 menandakan bahwa perseroan menggunakan utang untuk pengeluaran perseroan sebesar $87 \%$. Nilai mean untuk variabel ukuran perusahaan yakni 20,025 menunjukkan bahwa perseroan sampel memiliki ukuran perusahaan sebesar 20,025 . Nilai mean untuk variabel umur perusahaan yakni 13,590 menunjukkan bahwa rata-rata perseroan sampel telah IPO selama tiga belas tahun.

Tabel 3. Uji Chow

\begin{tabular}{cccc}
\hline & Uji Chow & $\begin{array}{c}\text { Uji Lagrange } \\
\text { Multipliers }\end{array}$ & Uji Hausman \\
\hline Probability Restricted & 0,000 & 0,001 & 0,358 \\
$\alpha$ & 0,05 & 0,05 & 0,05 \\
\hline
\end{tabular}

Merujuk Tabel 3 di atas, setelah dilakukan uji chow nilai probability $<\alpha$, maka model yang dipilih yakni fixed effect model. Kemudian, dilakukan uji lagrange multipliers dengan nilai Breush-Pagan $<0,05$ maka model yang digunakan yakni random effect. Terakhir, Uji Hausman nilai probability $<\alpha$ maka model terbaik yang dipakai dalam penelitian yakni random effect model.

Sebelum dilakukan uji hipotesis melalui analisis regresi linear berganda, terlebih dahulu perlu dilakukan pengujian asumsi klasik, yang terdiri atas uji normalitas, multikolinieritas, autokorelasi dan heterokedastisitas. Berdasarkan penjelasan tersebut, maka dalam penelitian ini uji asumsi klasik memiliki output data sebagai berikut: 
Dhinda Nuramalia: Menilik Penghindaraan Pajak ...

Tabel 4. Uji Normalitas

\begin{tabular}{lll}
\hline Variabel & Skewness & Kurtosis \\
\hline Composite & 0,102 & 2,818 \\
CSRIJ & 1,048 & 3,629 \\
KI & 1,469 & 3,351 \\
ROA_w & 0,913 & 3,771 \\
LEV_w & $-0,046$ & 5,603 \\
SIZE & 0,323 & 2,756 \\
Age & 0,477 & 2,145 \\
\hline
\end{tabular}

Persyaratan yang harus dipenuhi dalam pengujian normalitas menggunakan skewness dan kurtosis, yakni nilai skewness di bawah dua dan nilai kurtosis di bawah sepuluh maka data akan terbilang normal. Data awalnya tidak terdistribusi secara normal, tetapi dapat diatasi dengan melakukan winsorized (3 97). Tabel 4 di atas merupakan hasil normalitas setelah treatment winsorized.

Tabel 5. Uji Koefisien Determinasi

\begin{tabular}{cc}
\hline Number of Obs & 110 \\
Prob $>$ F & 0,001 \\
R-Squared & 0,035 \\
\hline
\end{tabular}

Merujuk pada Tabel 5, hasil membuktikan nilai within $R$-squared sebesar 0,035, maknanya pengaruh variabel pengungkapan corporate social responsibility, kepemilikan institusional, profitabilitas, leverage, ukuran perusahaan, dan umur perusahaan mampu menjelaskan 3,5\% terhadap variabel agresivitas pajak pada perseroan pertambangan yang terdaftar di Bursa Efek Indonesia tahun 20162020.

Tabel 6. Uji Hipotesis

\begin{tabular}{lllll}
\hline Composite & $\begin{array}{l}\text { Predicted } \\
\text { Sign }\end{array}$ & Coef. & $\mathbf{z}$ & P > |z| \\
\hline CSRIJ & - & $-0,058$ & $-0,31$ & 0,756 \\
KI & - & 0,052 & 0,57 & 0,570 \\
ROA_w & + & $-0,028$ & $-0,12$ & 0,902 \\
LEV_w & - & 0,042 & 2,91 & $0,004 *$ \\
SIZE & - & 0,004 & 0,53 & 0,594 \\
Age & + & $-0,005$ & $-1,63$ & 0,103 \\
Cons_ & + -- & 0,460 & 2,29 & 0,022 \\
\hline
\end{tabular}

Keterangan: *signifikan $5 \%$

Merujuk Tabel 6 di atas, hipotesis pertama dalam penelitian ini yakni pengungkapan corporate social responsibility berpengaruh negatif terhadap agresivitas pajak. Pada tabel di atas menjelaskan bahwa nilai probabilitas variabel corporate social responsibility sebesar 0,756 nilai tersebut $>0,05$ 
dengan coefficient negatif. Maka dapat disimpulkan variabel corporate social responsibility tidak berpengaruh terhadap agresivitas pajak pada perseroan pertambangan yang terdaftar di BEI tahun 2016-2020, hipotesis satu ditolak. Maknanya tinggi rendahnya tingkat pengungkapan corporate social responsibility tidak mempengaruhi perseroan dalam melakukan agresivitas pajak. Dalam teori legitimasi dijelaskan bahwa corporate social responsibility yakni usaha yang dilakukan perseroan untuk mendapatkan legitimasi atau pengakuan dari masyarakat tempat perseroan beroperasi. Hal ini dilakukan oleh perseroan sebagai bentuk perhatian perseroan terhadap lingkungan sekitarnya. Terkait dengan halhal yang mendasari perseroan untuk mengungkapkan tanggung jawab sosialnya menurut Mardikanto (2014) beberapa di antaranya yakni berkaitan dengan reputasi perseroan, lalu dapat dijadikan keunggulan kompetitif, terdorong dari komitmen dewan komisaris, dan adanya tuntutan dari pelanggan.

Hasil penelitian ini sejalan dengan Liu \& Lee (2019) yang menjelaskan bahwa perseroan dituntut untuk memenuhi tanggung jawab sosial dalam menanggapi kekhawatiran yang berkembang mengenai masalah sosial dan lingkungan yang menyertai pertumbuhan ekonomi yang pesat dan Makhfudloh, dkk. (2018) menjelaskan bahwa informasi pengungkapan tanggung jawab sosial yang dilaporkan perseroan belum tentu sesuai dengan keadaan yang sebenarnya terjadi, sehingga hal ini tidak dapat dijadikan acuan akan rendahnya tindakan agresivitas pajak yang dilakukan perseroan.

Hipotesis kedua dalam penelitian ini yakni kepemilikan institusional berpengaruh negatif terhadap agresivitas pajak. Pada tabel di atas menjelaskan bahwa nilai probabilitas variabel kepemilikan institusional sebesar 0,570 nilai tersebut $>0,05$ dengan coefficient positif. Maka dapat disimpulkan variabel kepemilikan institusional tidak berpengaruh terhadap agresivitas pajak pada perseroan pertambangan yang terdaftar di BEI tahun 2016-2020, hipotesis dua ditolak. Hasil ini tidak mendukung teori agency karena dijelaskan adanya hubungan antara pemegang saham dengan manajemen, dalam kaitannya dengan kepemilikan institusional agent yakni pihak manajemen dalam menjalankan operasional perseroanakan berusaha untuk memperhatikan kepentingan para principal, hal ini dilakukan untuk meminimalisir konflik keagenan. Namun, dalam penelitian ini menunjukkan peran principal sangat dominan dalam menentukan kebijakan perusahaan.

Hasil penelitian ini sejalan dengan Arianandini \& Ramantha (2018) dan Suprimarini \& Suprasto (2017) menjelaskan keberadaan struktur kepemilikan institusional mengindikasikan adanya tekanan pada manajemen untuk melakukan agresifitas pajak agar laba yang dibagikan pada pemegang saham menjadi maksimal, peran kepemilikan institusional sebagai pihak yang memonitor perusahaan belum tentu mampu memberikan kontrol yang baik terhadap tindakan manajemen atas oportunistiknya dalam melakukan praktik tax avoidance.

Hipotesis ketiga dalam penelitian ini yakni profitabilitas berpengaruh positif terhadap agresivitas pajak. Pada tabel di atas menjelaskan bahwa nilai probabilitas variabel profitabilitas sebesar 0,902 nilai tersebut $>0,05$ dengan coefficient negatif. Maka dapat disimpulkan variabel profitabilitas tidak berpengaruh terhadap agresivitas pajak pada perseroanpertambangan yang terdaftar di BEI tahun 2016-2020, hipotesis ketiga ditolak. Dalam teori agency menjelaskan mengenai hubungan kontrak antara pemegang saham dengan manajemen sebagai agen yang bertugas dalam mengelola perseroan. Agen dalam mengelola perseroan harus mementingkan dan sejalan dengan tujuan pemegang saham yakni memperoleh laba yang besar untuk perseroan. Hasil penelitian ini sejalan dengan Rista \& Mulyani (2019) dan Savitri \& Rahmawati (2017) yang menjelaskan perseroan yang memiliki profitabilitas yang besar akan menggunakan keuntungannya untuk memperluas usaha dan tidak memikirkan untuk melakukan tindakan agresivitas pajak, dan begitu juga yang memiliki keuntungan kecil tidak akan melakukan agresivitas pajak karena beban pajaknya kecil.

Variabel kontrol, yakni leverage merujuk tabel di atas memiliki nilai probabilitas sebesar 0,004 
Dhinda Nuramalia: Menilik Penghindaraan Pajak ...

nilai tersebut $<0,05$ dengan coefficient positif. Maka dapat disimpulkan variabel leverage berpengaruh positif terhadap agresivitas pajak pada perseroan pertambangan yang terdaftar di BEI tahun 2016-2020. Variabel ukuran perusahaan pada tabel di atas menunjukkan nilai probabilitas sebesar 0,594 nilai tersebut $>0,05$ dengan coefficient positif maka dapat disimpulkan bahwa variabel ukuran perusahaan tidak berpengaruh terhadap agresivitas pajak pada perseroan pertambangan yang terdaftar di BEI tahun 2016-2020. Variabel umur perusahaandalam tabel di atas menunjukkan nilai probabilitas 0,103 nilai tersebut $>0,05$ dengan coefficient negatif, maka dapat disimpulkan variabel umur perusahaan tidak berpengaruh terhadap agresivitas pajak pada perseroan pertambangan yang terdaftar di BEI tahun 20162020.

\section{KESIMPULAN}

Merujuk dari pembahasan bahwa corporate social responsibility, kepemilikan institusional dan profitabilitas terbukti tidak mempengaruhi perseroan dalam melakukan agresivitas pajak. Variabel kontrol yakni leverage, ukuran perusahaan dan umur perusahaan hanya leverage yang memiliki pengaruh bagi perseroan dalam melakukan agresivitas pajak. Pada riset ini terdapat variabel corporate social responsibility terdapat perseroan-perseroan yang tidak menerbitkan sustainability report pada tahun penelitian sehingga perlu beberapa judgement atas item-item yang diungkap manajemen dalam laporan tahunan sehingga judgment tersebut mungkin terlalu kecil atau sedikit dibandingkan perseroan lain yang memiliki detail item pengungkapan dalam sustainability report. Hasil penelitian ini berimplikasi bahwa pada periode penelitian, aktivitas manajer terkait tanggung jawabnya terhadap lingkungan dan masyarakat tidak berorientasi pada pajak perusahaan, tetapi didasarkan untuk keberlanjutan operasional perusahaan (sustainability operation). Demikian pula pemilik yang berasal dari institusi melakukan pengawasan dan pengendalian pada manajer pada aspek strategis lain selain pajak perusahaan. Profitabilitas perusahaan tidak menjadi hal yang dapat mendorong manajer melakukan aktivitas penghindaran pajak, terlebih pada saat masa pandemi sekarang ini banyak sekali insentif dan kebijakan yang dikeluarkan oleh Dirjen pajak untuk mendorong keberlangsungan ekonomi wajib pajak.

\section{DAFTAR PUSTAKA}

Adiputra, I. M. P., Martani, D., \& Matadinata, I. P. H. (2019). The Effect Of Corporate Social Responsibility Disclosure And Corporate Governance On Aggressive Tax Action. Journal of Economics, Business \& Accountancy Ventura, 22(2), 237-247. https://doi.org/10.14414/jebav.v22i2.1295

Alkurdi, A., \& Mardini, G. H. (2020). The Impact Of Ownership Structure And The Board Of Directors' Composition On Tax Avoidance Strategies: Empirical Evidence From Jordan. Journal Of Financial Reporting And Accounting, 18(4), 795-812. https://doi.org/10.1108/JFRA-01-2020-0001

Andhari, P. A. S., \& Sukartha, I. M. (2017). Pengaruh Pengungkapan Corporate Social Responsibility, Profitabilitas, Inventory Intensity, Capital Intensity dan Leverage Pada Agresivitas Pajak. E-Jurnal Akuntansi Universitas Udayana, 18(3), 2115-2142. https://doi.org/10.35760/eb.2020.v25i3.2853

Arianandini, P. W., \& Ramantha, I. W. (2018). Pengaruh Profitabilitas, Leverage, dan Kepemilikan Institusional Pada Tax Avoidance. E-Jurnal Akuntansi, 22(3), 2088-2116. https://doi.org/10.24843/eja.2018.v22.i03.p17

Arieftiara, D., Utama, S., Wardhani, R., \& Rahayu, N. (2020). Contingent Fit Between Business Strategies And Environmental Uncertainty: The Impact On Corporate Tax Avoidance In Indonesia. Meditari Accountancy Research, 28(1), 139-167. https://doi.org/10.1108/MEDAR-05-2018-0338

Ching, H. Y., Gerab, F., \& Toste, T. H. (2017). The Quality of Sustainability Reports and Corporate Financial Performance: Evidence From Brazilian Listed Companies. SAGE Open, 7(2). https://doi.org/10.1177/2158244017712027 
Comprix, J., Graham, R. C., \& Moore, J. A. (2011). Empirical Evidence On The Impact Of Book-Tax Differences On Divergence Of Opinion Among Investors. Journal of the American Taxation Association, 33(1), 51-78. https://doi.org/10.2308/jata.2011.33.1.51

Deswanto, R. B., \& Siregar, S. V. (2018). The Associations Between Environmental Disclosures With Financial Performance, Environmental Performance, And Firm Value. Social Responsibility Journal, 14(1), 180-193. https://doi.org/10.1108/SRJ-01-2017-0005

Dowling, J., \& Pfeffer, J. (1975). Organizational Legitimacy: Social Values And Organizational Behavior. Sociological Perspectives, 18(1), 122-136. https://doi.org/10.2307/1388226

Frank, M. M., Lynch, L. J., \& Rego, S. O. (2009). Tax Reporting Aggressiveness And Its Relation To Aggressive Financial Reporting. Accounting Review, 84(2), 467-496. https://doi.org/10.2308/accr.2009.84.2.467

Hakim, F. (2020). Analisis Pengaruh Corporate Governance Terhadap Penghindaran Pajak (Studi Empiris Pada Perseroan Pertambangan Yang Terdaftar Pada Bursa Efek Indonesia Tahun2015-2017). Jurnal Ilmiah Mahasiswa, 01(8), 1689-1699.

Jensen, M.C., \& Meckling, W. H. (1976). Theory Of The Firm - Managerial Behaviour, Agency Cost And Ownership Structure. Journal of Financial Economics, 3, 305-360.

Jessica, A. A. T. (2014). Pengaruh Pengungkapan Corporate Social Responsibility Terhadap Agresivitas Pajak. Tax \& Accounting Review, 4(1), 193-203.

Jurnal Enterpreneur. (2017). 4 Manfaat Membayar Pajak bagi Perusahaan. Jurnal Enterpreneur. https://jurnal.id/id/blog/2017-3-manfaat-membayar-pajak-bagi-pengusaha/

Lanis, R., \& Richardson, G. (2013). Corporate Social Responsibility And Tax Aggressiveness: A Test Of Legitimacy Theory. Accounting, Auditing and Accountability Journal, 26(1), 75-100. https://doi.org/10.1108/09513571311285621

Liu, H., \& Lee, H. A. (2019). The Effect Of Corporate Social Responsibility On Earnings Management And Tax Avoidance In Chinese Listed Companies. International Journal of Accounting and Information Management, 27(4), 632-652. https://doi.org/10.1108/IJAIM-08-2018-0095

Makhfudloh, F., Nurul, H., Wulandari, A. (2018). Pengaruh Corporate Social Responsibility Terhadap Perencanaan Agresivitas Pajak. Jurnal Akuntansi Dan Bisnis, 18(1), 48-60.

Nugrahitha, I. M. A., \& Suprasto, H. B. (2018). Pengaruh Profitabilitas, Leverage, Corporate Governance, dan Karakter Eksekutif pada Tax Avoidance. E-Jurnal Akuntansi Universitas Udayana, 22(3), 20162039. https://doi.org/10.24843/EJA.2018.v22.i03.p14

Nuraeni, A. (2015, Oktober 19). Jangan Ampuni Perusahaan Tambang Pelaku Kejahatan Perpajakan!!! PWYP Indonesia. https://pwypindonesia.org/id/jangan-ampuni-perusahaan-tambang-pelakukejahatan-perpajakan/

Praditasari, A. \& Setiawan, P. E. (2017). Pengaruh Good Corporate Governance, Ukuran Perusahaan, Leverage Dan Profitabilitas Pada Tax Avoidance. E-Jurnal Akuntansi, 2017(1), 1229-1258.

Pranata, F. M, Puspa, D. F., \& Herawati. (2014). Pengaruh Karakter Eksekutif Dan Corporate Governance Terhadap Tax Avoidance. E. E-Jurnal Bung Hatta, 4(1), 1-13.

Prasista, P. M. \& Setiawan, E. (2016). Pengaruh Profitabilitas Dan Pengungkapan Corporate Social Responsibility Terhadap Agresivitas Pajak Penghasilan Wajib Pajak Badan. E-Jurnal Akuntansi, 17(3), 2120-2144.

Rahman, K. (2009, Oktober 28). Pencemaran Limbah PT Adaro, Lumpuhkan Balangan, dan Amuntai. Tempo. https://nasional.tempo.co/read/204966/pencemaran-limbah-pt-adaro-lumpuhkanbalangan-dan-amuntai 
Dhinda Nuramalia: Menilik Penghindaraan Pajak ...

Redaksi. (2016, Agustus 31). KPK: Perusahaan Tambang Banyak Mengemplang Pajak. Klinik Pajak. http://www.klinikpajak.co.id/berita+detail/?kategori=semua+kategori\&id=berita+pajak++kpk\%3A+perusahaan+tambang+banyak+mengemplang+pajak

Reminda, A. D. (2017). Pengaruh Corporate Social Responsibility, Profitabilitas, Ukuran perusahaan, Dan Capital Intensity Terhadap Agresivitas Pajak (Studi Empiris pada Perseroan Perbankan yang Terdaftar di BEl Periode Tahun 2013-2015 ). JOM Fekon, 4(2), 4279-4293.

Rista, B., \& Mulyani, S.D. (2019). Pengaruh Corporate Social Responsibility dan Profitabilitas terhadap Penghindaran Pajak Perusahaan dengan Peran Komite Audit sebagai Moderasi. Prosiding Seminar Nasional, 2, 1-10.

Savitri, D. A. M., \& Rahmawati, I. N. (2017). Pengaruh Leverage, Intensitas Persediaan, Intensitas Aset Tetap dan Profitabilitas Terhadap Agresivitas Pajak. Jurnal IImu Manajemen Dan Akuntansi Terapan (JIMAT), 8(2), 19-32.

Setiawan, D. A. (2020, Januari 7). Penerimaan Pajak 2019 Capai 84,4\% dari Target, Ini Data Lengkapnya. DDTC News. https://news.ddtc.co.id/penerimaan-pajak-2019-capai-844-dari-target-ini-datalengkapnya-18309

Sujudi, A. A., Sofianty, D., \& Nurleli. (2019). Pengaruh Pengungkapan Corporate Social Responsibility dan Kepemilikan Institusional terhadap Tax Avoidance. Prosiding Akuntansi, 5(2), 248-254.

Suprimarini, N. P. D., \& Suprasto, B.. (2017). Pengaruh Corporate Social Responsibility, Kualitas Audit, Dan Kepemilikan Institusional Pada Agresivitas Pajak. E-Jurnal Akuntansi Universitas Udayana, 19(2), 1349-1377.

Tandean, V. A., \& Winnie, W. (2016). The Effect of Good Corporate Governance on Tax Avoidance: An Empirical Study on Manufacturing Companies Listed in IDX period 2010-2013. Asian Journal of Accounting Research, 1(1), 28-38. https://doi.org/10.1108/ajar-2016-01-01-b004

Tang, T., \& Firth, M. (2011). Can Book-Tax Differences Capture Earnings Management and Tax Management? Empirical Evidence from China. The International Journal of Accounting, Forthcoming, 46(2), 1-49. https://doi.org/10.1016/j/intacc.2011.04.005

Warsito \& Lindiasari, S. P. (2020). Potensi Penurunan Pajak dan Strategi Kebijakan Pajak Untuk Mengantisipasi Dampak Pandemi Covid-19: Perspektif Ketahanan Nasional. Jurnal Ekonomi \& Kebijakan Publik, 11(2), 93-108.

Wijaya, D., \& Saebani, A. (2019). Pengaruh Pengungkapan Corporate Social Responsibility, Leverage, Dan Kepemilikan Manajerial Terhadap Agresivitas Pajak. Widyakala Journal, 6(1), 55. https://doi.org/10.36262/widyakala.v6i1.14

Zsazya. (2019, November 19). Agresivitas Pajak, Simak Pemahaman dan Risikonya disini!. Online Pajak. https://www.online-pajak.com/tentang-pph-final/agresivitas-pajak 